\title{
POST-WILDLAND FIRE DESERTIFICATION: CAN REHABILITATION TREATMENTS MAKE A DIFFERENCE?
}

\author{
Daniel G. Neary \\ US Forest Service, Rocky Mountain Research Station, \\ Flagstaff, Arizona 86001, USA \\ Tel.: 001-928-556-2176; e-mail: dneary@fs.fed.us
}

\begin{abstract}
Desertification, caused by land degradation as opposed to the immediate creation of classical deserts, is of prime concern in the 21 st century. As a result of human activities and climate change, the land loses its proper hydrologic function and biological productivity. Desertification affects $33 \%$ of the earth's surface and over a billion people. Fire-related desertification has a number of environmental, social, and economic consequences. The two key environmental consequences are soil erosion and non-native plant invasions. Erosion after wildland fires can be in the range of $<1 \mathrm{Mg} \mathrm{ha}^{-1}$ to $370 \mathrm{Mg} \mathrm{ha}^{-1}$, depending on fire severity, degree of water repellency, slope, and post-fire rainfall events. Soil losses in the high end of that range definitely exceed soil loss tolerances and contribute to desertification. Non-native plants are typically ten times as abundant on landscapes burned by wildland fires than on unburned lands. Seeding has been used for many years as a prime Burned Area Emergency Response (BAER) treatment. Until recently, this seeding contributed to non-native plant invasions because fast-growing but non native plant seeds were used. The use of native plant seeds and sterile hybrids has reduced this problem somewhat. However, even certified weed-free seed lots have low percentages of non-native plant seeds. Recent use of wet and dry mulches have contributed to reduced postwildland fire erosion rates, but they are quite expensive. This paper examines post-wildland fire desertification and the capabilities of BAER treatments to deal with this growing problem.
\end{abstract}

Keywords: Burned Area Emergency Response, desertification, non-native plants, soil erosion, wildland fire

Citation: Neary, D.G. 2009. Post-wildland fire desertification: can rehabilitation treatments make a difference? Fire Ecology 5(1): 129-144. doi: 10.4996/fireecology.0501129

\section{INTRODUCTION}

Wildland fire is a world-wide natural phenomenon that began with the development of terrestrial vegetation in a lightning-filled atmosphere (Pyne 1995). Sediments from the Carboniferous Period (307 to 359 million years before the present) contain evidence of char- coal from post-fire ash slurry flows (Scott 2000). As human populations developed in the Pleistocene and Holocene epochs, humankind transformed fire into one of its oldest tools. Human and lightning ignited fires altered and steered the trajectories of ecosystem development in most parts of the world. The primary source of forest and grass fire ignitions 
throughout the world is human activity, although lightning plays a major role (Pyne 1995). As human populations have increased and industrialized in the past two centuries, fire ignitions and burned areas have increased due to sheer numbers of people and anthropogenic changes in the global climate. An example can be seen in a MODIS satellite generated image of global fires during the period of 2005 (Figure 1; Davies et al. 2004).

Recent scientific findings have bolstered the hypothesis that climate change is resulting in fire seasons starting earlier, lasting longer, burning greater areas, and being more severe (Tebaldi et al. 2006, Westerling et al. 2006). Computer models developed by Tebaldi et al. (2006) point to the western USA, Mediterranean nations, and Brazil as hot spots that will commonly experience extreme fire behavior. The climatic change to drier and warmer conditions is already aggravating wildland fire conditions in the USA, the Mediterranaean, and Australia. These conditions are expected to continue well into the $21^{\text {st }}$ century. Wildland fire can have positive, neutral, or negative impacts on ecosystems and their components. A negative impact of prime concern in the $21^{\text {st }}$ century is desertification.

Pre-fire treatments that reduce the risk of soil damage and non-native plant invasions are preferred to high severity catastrophic wildland fires that initiate desertification (DeBano et al. 1998, Neary et al. 2005). Thinning of over-stocked stands and the introduction of prescribed fires have ecosystem impacts, but they are substantially less that those produced by wildland fires (Neary and Hornbeck 1994, Neary 2002). DeBano et al. (2005) clearly point out that sediment losses from typical silviculture operations are in the range of 0.04 to 15.00 $\mathrm{Mg} \mathrm{ha}^{-1}$. Prescribed fires typically produce sediment losses of $0.00 \mathrm{Mg} \mathrm{ha}^{-1}$ to 8.44 $\mathrm{Mg} \mathrm{ha}^{-1}$, with most $<0.80 \mathrm{Mg} \mathrm{ha}^{-1}$. On the other hand, wildland fires commonly result in soil erosion rates $>20 \mathrm{Mg} \mathrm{ha}^{-1}$ and going up as high as $370 \mathrm{Mg} \mathrm{ha}^{-1}$. High severity wildland fires are clearly the issue of concern in regard to desertification in forests, woodlands, and scrublands.

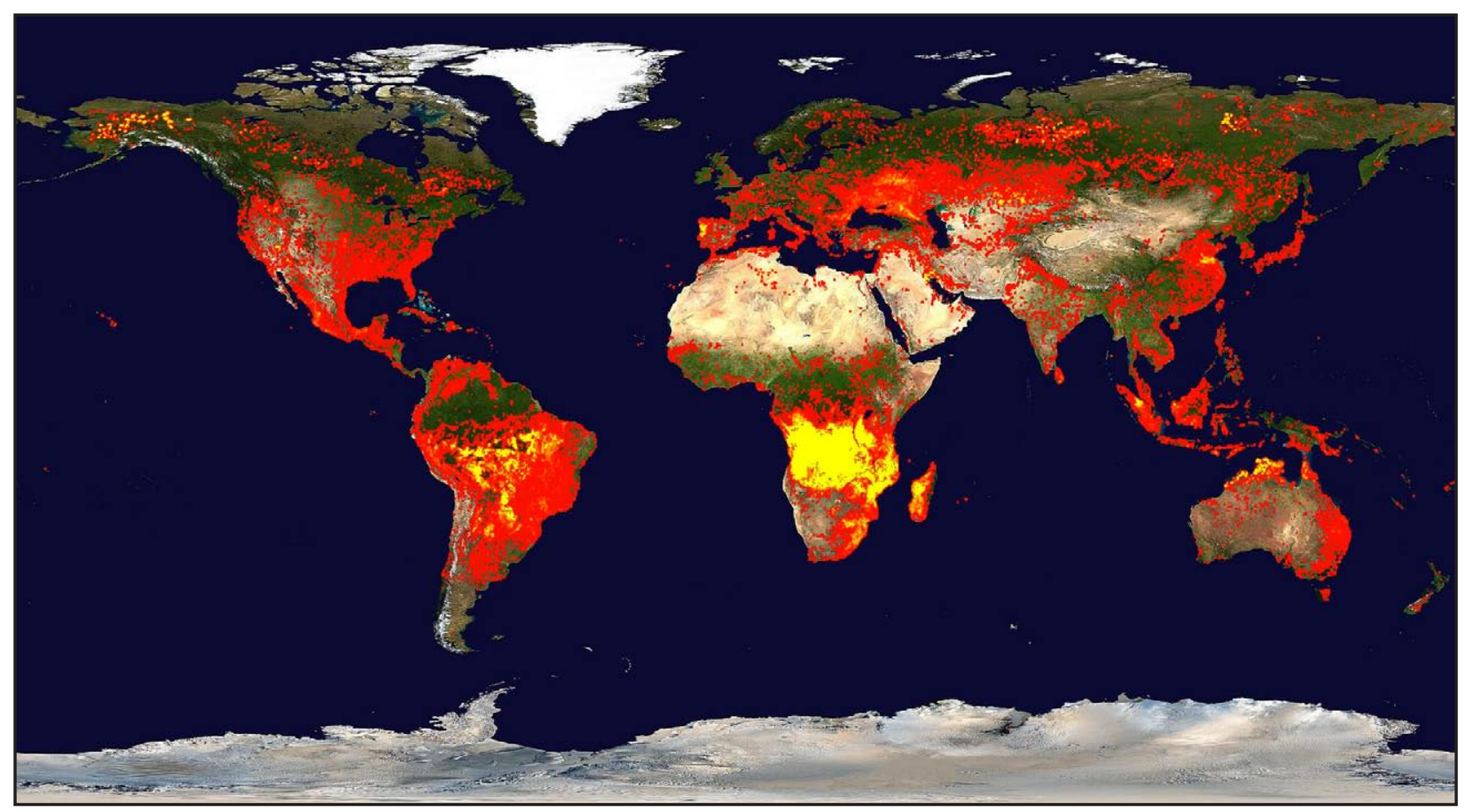

Figure 1. Global fires from MODIS satellite imagery 1 June 2005 through 31 August 2005. Yellow indicates regions of high fire frequency. (NASA 2006; http://rapidfire.sci.gsfc.nasa.gov/firemaps/.) 
Although discussion of land management treatments that reduce the soil erosion component of desertification is a worthy exercise, a detailed discussion of the topic is beyond the objectives and scope of this paper. In the past decade, wildland fires have expanded in area and severity in response to unprecedented fuel build-ups and climate change that has produced longer, hotter, and drier summers. It is important that the potential impacts of these climate-fire behavior links are understood. In this paper, I will examine the contributions of these wildland fires to the desertification process, and the ability of post-wildland fire management actions to mitigate the adverse impacts.

\section{DESERTIFICATION}

\section{Description}

Desertification is a human-induced or natural process that negatively affects the ability of an ecosystem to accept, store, or recycle water, nutrients and energy. Desertification is not necessarily the immediate creation of classical deserts such as the Sahara, Gobi, Sonoran, or Atacama deserts (Aubreville 1949, Dregne 1986, Walker 1997). These desert landscapes are more one type of end point of the desertification process. Although desertification is commonly thought of as land degradation that is a problem of arid, semiarid, and dry sub-humid regions of the world, humid regions such as Brazil and Indonesia are now experiencing desertification because of wide-scale deforestation and fire use. Three salient features of desertification are soil erosion, reduced biodiversity, and the loss of productive capacity, such as the transition from grassland dominated by perennial grasses to one dominated by perennial shrubs. For example, in the southwestern United States, semiarid grassland ecosystems dominated by the perennial bunchgrasses such as Lemon grass (Andropogon cir- ratus), sideoats grama (Bouteloua curtipendula), and spiked crinkleawn (Trachypogon secundus) were replaced by shrublands dominated by creosotebush (Larrea tridentata) and mesquite (Prosopis spp.) as a result of overgrazing since the late 1800s (Brown 1982). This change in vegetation has resulted in desertification in this region.

Wildland fire is now driving desertification in some of the forests in the western USA, the Mediterranean area, and Australia. The western USA has been experiencing a substantial drought over the past decade (Soulé 2006). The area burned by wildland fire in the southwest USA has increased dramatically in the past two decades (Figure 2). Individual wildland fires are now larger and produce higher severity burns than in the past (Westerling et al. 2006). A combination of drought, climate change, fuel load build-ups, and increased ignition sources have produced the conditions for fire-induced desertification (DeBano et al. 1998, Neary et al. 2005). From 2004 through 2007, the USA had

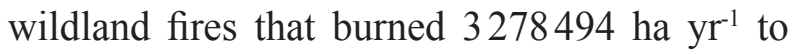

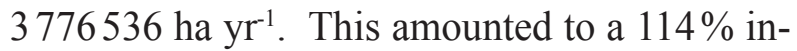
crease over the $40 \mathrm{yr}$ wildland fire burned area average of 1530793 ha.

Portugal suffered the worst and second worst wildland fire seasons in a three-year period (2003 through 2005). In 2005, 338262 ha of forest land burned (Neary 2006). This was

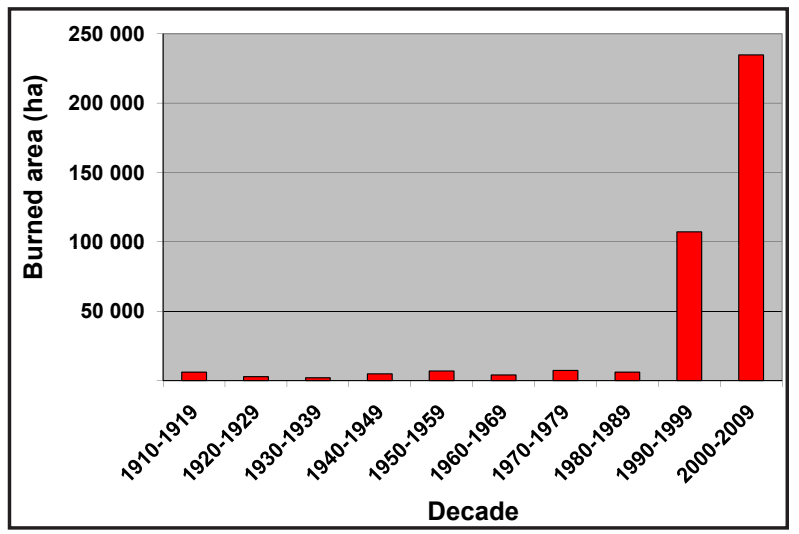

Figure 2. Wildland fire area in the southwest USA, annual average by decade (1910 through 2005) (Neary 2006). 
a $77 \%$ increase over the $10 \mathrm{yr}$ burn average of 189500 ha. Portugal has been experiencing one of its worst droughts ever, and the dry conditions have led to extensive wildland fires (Pires and Silva 2008). Besides the lack of rainfall, temperatures were also higher than normal (European Commission 2006). Other countries such as Indonesia and Australia are experiencing the same trend. Clearly, this is a world-wide trend linked to climate change and is not isolated to the USA.

It is a common misunderstanding that droughts cause desertification because dry periods are common in arid and semiarid lands and are part of the ebb and flow of climate in these regions (Walker 1997). Well-managed lands can recover from the dry segments of climate cycles when rainfall increases. However, continued land abuse from agriculture, grazing, forest harvesting, wildland fire, and mining during droughts certainly increases the potential for permanent land degradation (MacDonald 2000). Desertification results in the loss of the land's proper hydrologic function, biological productivity, and other ecosystem services as a result of human activities and climate change (Black 1997; Walker 1997; Millenium Ecosystem Assessment 2005a, b). Desertification affects one third of the earth's surface and over a billion people. In the past, desertification was considered a problem of only arid, semiarid, and dry sub-humid areas. However, humid zones can also undergo desertification with the cumulative effects of human impacts (MacDonald 2000). The Amazon region is an example of where forest harvesting, shifting cut-and-burn agriculture, and large-scale grazing are producing desertification of a tropical rain forest on a large scale (Malhi et al. 2008).

Desertification is a complex process. It involves multiple causes and proceeds at varying rates in different climates. Desertification may intensify a general climatic trend toward greater aridity, or it may initiate a change in local climate. Desertification does not occur in straight-forward, easily predictable patterns that can be rigorously mapped. Deserts advance erratically, forming patches on their borders. Areas far from natural deserts can degrade quickly to barren soil or rock through poor land management. The proximity of a nearby desert has no direct relationship to desertification. Unfortunately, areas subjected to the process of desertification are brought to professional or public attention only after the process is well underway. This is especially true in regions where little or no data are available to indicate the previous state of the ecosystem or the rate of degradation. Scientists and many land managers are beginning to recognize that is a process that is part of global climate change (Reynolds and Stafford-Smith 2002, Stringer 2006, FAO 2009, UNCCD 2009).

The permanence of desertification depends on the framework used to evaluate this geomorphic process. Efforts are now underway by natural resources science and management agencies to determine the social, environmental, and economic costs of desertification potentially facing countries in the short- and long-term and how those costs should be addressed (Requier-Desjardins 2006). Fire-related desertification has many of the same costs with the addition of substantial impacts in the short-term.

Some of the environmental consequences of wildland fires are vegetation mortality, plant species and type shifts, non-native plant invasions, wildlife habitat alteration, soil erosion, floods, watershed function changes, water supply disruption, and air pollution. All of these are immediate impacts. Small, isolated burned areas do not produce noticeable desertification, but the cumulative effect of multiple, large area, and adjacent fires can be landscape-level desertification.

Vegetation mortality encompasses the temporary loss of timber-producing roundwood 
and regeneration stock, as well as herbaceous flora (Brown and Smith 2000). Forests can be replanted or regenerated naturally after fires, but there will be a period of time, from $30 \mathrm{yr}$ to $200+\mathrm{yr}$, when burned sites are degraded in terms of wood production. In addition, landscape-scale species type shifts can occur. For example, large areas of ponderosa pine (Pinus ponderosa) stands (20000+ ha) within high-severity fire portions of the 2002 Rodeo-Chediski Fire, Arizona, were converted to a chaparral (evergreen oak [Quercus spp.] and related species) type due to the loss of pine regeneration and the seed reservoir in the soil. Without planting of seedlings, these areas will take centuries to return to their pre-fire productive state. Herbaceous plants often recover rapidly after fires, increasing plant diversity and productivity in the short-term. However, areas with highseverity wildland fire may recover slowly (Neary et al. 2005). These sites are also subject to non-native plant invasions that may dramatically reduce biodiversity. These invasions are difficult and expensive to reverse. Fire affects animals mainly through changing the vegetative structure of their habitat (Smith 2000). Fire usually causes short-term improvements in wildlife foods that then result in wildlife population increases. Some species may be negatively affected by changes in the structure of forests after wildland fire (e.g., removal of canopies).

\section{Classification}

There are four site-specific desertification categories with criteria that are directly linked to soil erosion and plant species composition: very severe, severe, moderate, and slight to none (Dregne 1986; Table 1). The very severe category represents the situation of badly degraded land that is considered to be unusable and deteriorated beyond economically feasible restoration. In the past, drought, overgrazing, and wind erosion have been the leading factors
Table 1. Desertification classification system categories (After Dregne 1986).

\begin{tabular}{lcc}
\hline $\begin{array}{l}\text { Desertification } \\
\text { category }\end{array}$ & $\begin{array}{c}\text { Topsoil loss } \\
\text { (\%) }\end{array}$ & $\begin{array}{c}\text { Climax plant } \\
\text { species (\%) }\end{array}$ \\
\hline None to slight & None to $<25$ & 100 \\
Moderate & 25 to 75 & 26 to 50 \\
Severe & $>95$ & 10 to 25 \\
Very severe & $\begin{array}{c}\text { Gullies } \\
\text { developed }\end{array}$ & $<10$ \\
\hline
\end{tabular}

of desertification in the southerwestern USA. With the advent of large, high severity megafires (generally $>30000 \mathrm{ha}$ ) in the past two decades, wildland fire has assumed an important role in desertification (Neary et al. 2005). Mega-fires are defined as wildland fires that are extraordinary in terms of their size, complexity, and resistance to control (Williams and Hamilton 2005).

Classification of desertification has facilitated analysis at national and continental scales (Table 2). Arid lands are much more prone to desertification as $81 \%$ fall into the slight to moderate category (Dregne 1986). A somewhat higher value was estimated for North America arid lands (90\%). Area-wide desertification classifications use additional criteria within Dregne's (1986) four-class system (Table 1). These criteria include plant cover, plant productivity declines, geomorphic evidence of desertification (e.g., dunes, gullies, and hummocks), soil salinity increases, undesireable

Table 2. Desertification wide area map classification criteria (After Dregne 1986).

\begin{tabular}{cl}
$\begin{array}{c}\text { Map } \\
\text { classification }\end{array}$ & \multicolumn{1}{c}{$\begin{array}{c}\text { Area in desertification } \\
\text { categories (\%) }\end{array}$} \\
\hline \multirow{3}{*}{ Slight } & $>50$ slight \\
& $<20$ severe \\
& $<10$ very severe \\
\hline \multirow{2}{*}{ Moderate } & $<50$ slight \\
& $<30$ severe and very severe \\
\hline \multirow{2}{*}{ Severe } & $>30$ severe category \\
& 0 to 30 very severe \\
\hline Very severe & $>30$ very severe \\
\hline
\end{tabular}


forbs and shrubs, salt crusts, declines in soil permeability, soil stability, soil compaction, desertification spatial distribution, and departure from pristine conditions (Dregne 1977). The additional criteria give land managers a more in-depth understanding of the degree of desertification beyond topsoil loss and plant climax species changes.

\section{Degree of Desertification}

The degree of desertification is very much dependent on soil type, slope, climate, and the past erosional history. The degree of and susceptability to desertification can be assessed by the initial depth of a soil's A horizon and the subsequent loss of soil due to erosion. For example, a soil that is undisturbed and has a deep A horizon (Figure 3) can tolerate much higher erosion losses and is more resistent to desertification than one that has been previously disturbed by any combination of causes (Figure 3). Deep A horizon soils can potentially lose $3 \mathrm{~cm}$ of depth to a high severity wildland fire and rise to a slight desertification level. By contrast, a soil that has a thin A horizon and loses $3 \mathrm{~cm}$ of that layer would fall into the severe to very severe category (Table 3 ).

\section{Soil Loss Tolerance}

In some instances it is impossible to calculate percent loss of a soil's A horizon after wildland fire due to the lack of pre-fire data. If erosion rates are measured or estimated, the Natural Resource Conservation Service Soil Loss Tolerance rates can be used (Schmidt et al. 1982, Larson et al. 1983, NRCS 1993). The none to slight category in the desertification classification (Table 3 ) is then replaced by tolerable and low categories of soil loss tolerance (Table 4).

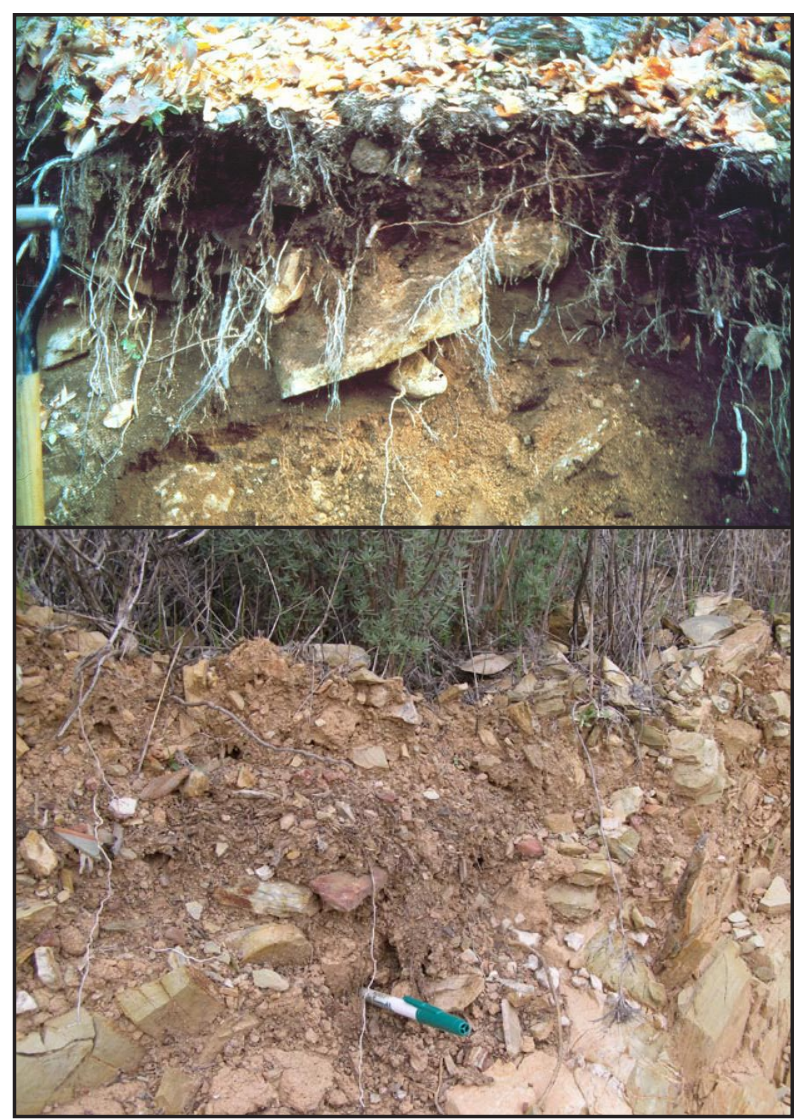

Figure 3. Undisturbed Lithic Hapludult Soil (top) and eroded Lithic Orthent Soil (bottom), forest soils from the Nantahala and Coronado Nationals Forests, respectively. (Photos by Daniel G. Neary.)

\section{POST-WILDLAND FIRE SOIL EROSION AND NON-NATIVE VEGETATION CHANGES}

\section{Erosion}

Soil degradation after wildland fires is a function of fire severity (Neary et al. 2005). Impacts can range from the minimal and shortterm to catastrophic and long-lasting. The most obvious impact is the loss of organic matter from combustion of the forest floor. Changes in soil physical and chemical properties with high-severity wildland fire can produce water repellency, increasing rainfall runoff and erosion. Because soils take long times to form (50 yr to $75000 \mathrm{yr}$ ), degradation as a result of wildland fire-related erosion or soil property 
Table 3. Effect of soil conditions and erosion on desertification classification

\begin{tabular}{cccccc}
\hline Soil & $\begin{array}{c}\text { A horizon depth } \\
\text { cm }\end{array}$ & $\begin{array}{c}\text { Slope } \\
\mathbf{\%}\end{array}$ & \begin{tabular}{c} 
Soil loss $^{\mathbf{1}} \mathbf{M g ~ h a}^{\mathbf{1}}$ \\
\multirow{2}{*}{ Undisturbed }
\end{tabular} $\begin{array}{c}\text { Loss of A horizon } \\
\mathbf{~ c m ~ ( \% ) ~}\end{array}^{\text {Desertification classification }}$ \\
\hline \multirow{2}{*}{ Eroded } & 16 & 10 & 109 & $1(6)$ & None to slight \\
& 16 & 66 & 311 & $3(18)$ & Slight \\
\hline
\end{tabular}

${ }^{1}$ Based on Rodeo-Chediski Fire of 2002, Garcia et al. 2005.

Table 4. Natural Resources Conservation Service (NRCS) soil loss tolerance rates. (From McCormack et al. 1979, NRCS 1993)

\begin{tabular}{lc}
\hline Soil erosion class & Soil loss $\mathbf{M g ~ h} \mathbf{~ a}^{-1}$ \\
\hline Tolerable (very low) & $<6.7$ \\
Low & 6.7 to 11.2 \\
Moderate & 11.2 to 22.4 \\
High & 22.4 to 33.6 \\
Severe & $>33.6$ \\
\hline
\end{tabular}

changes can result in severe and rapid desertification. Soil degradation is a one-way street not easily reversed during human life spans, especially when erosion rates exceed those of the severe category (Table 4; Larson et al. 1983, NRCS 1993). Although trees can be replanted on burned sites, soil lost by erosion cannot be replaced within human lifetimes; they can be rehabilitated to some degree but not restored. There are techniques to rehabilitate these degraded soils, such as deep mulching, organic matter additions, deep ripping, etc., but they are quite expensive and can be limitied by slope or access. Disruptions to soil micro-fauna and micro-flora can also reduce post-fire site vegetation productivity (Neary et al. 1999).

Soil erosion is a natural landscape process that, in the absence of catastrophic disturbance, proceeds in a linear or slightly linear trajectory (DeBano et al. 1998, 2005). High severity wildland fires provide the ecosystem stress that can push normal soil erosion across a threshold of irreversibility that leads to desertification and loss of ecosystem productivity (Dav- enport et al. 1998). The factors that determine whether soil erosion rates will cross a threshold in response to wildland fire include site erosion potential, which is a function of climate; geomorphology and soil erodibility; ground cover; soil disturbance history; soil type and horizon characteristics; and magnitude of disturbance. Mega-fires provide the stressor that can lead to soil erosion crossing a tolerance threshold and accelerating desertification.

Soil loss due to wildland fires can vary over four orders of magnitude, depending on soil type, soil cover, vegetation, slope, fire severity, rainfall intensity, and rainfall timing. Robichaud (2000, 2005) reported post-wildland fire erosion potentials from $2 \mathrm{Mg}^{-1}$ to $20000 \mathrm{Mg} \mathrm{ha}^{-1}$, but the higher estimates $(>500$ $\mathrm{Mg} \mathrm{ha}^{-1}$ ) involved substantial channel sediment entrainment in the total amount (Neary et al. 2005). Erosion from soil surfaces are more likely to be in the range of $1 \mathrm{Mg} \mathrm{ha}^{-1}$ to 500 $\mathrm{Mg} \mathrm{ha}^{-1}$, very much in the range of very severe desertification. In Arizona, soil surface erosion has been measured over three orders of magnitude (Table 5), with slope and rainfall intensities being the major aggravating factors. The mid-range amount of $109 \mathrm{Mg}^{-1}$ ha was from watersheds with slopes of $10 \%$ or less (Garcia et al. 2005). The amount of soil lost in this instance put it in the category of very severe desertification due to shallow soil (Table 3 ), and severe based on soil loss tolerance (33.6 $\mathrm{Mg} \mathrm{ha}^{-1}$; Table 4).

An environmental consequence of wildland fire related to soil disturbance and erosion 
Table 5. Soil surface erosion rates from Arizona wildland fires (DeBano et al. 2005).

\begin{tabular}{lccl}
\hline Vegetation type & $\begin{array}{c}\text { Amount } \\
\mathbf{M g ~ h a}^{-1} \mathbf{y r}^{-1}\end{array}$ & $\begin{array}{c}\text { Soil loss tolerance } \\
\text { category }\end{array}$ & \multicolumn{1}{c}{ Reference } \\
\hline Ponderosa pine & 1 & Tolerable & Campbell et al. 1977 \\
Chaparral & 29 & Moderate & Pace and Ingebo 1965 \\
Ponderosa pine & 109 & Severe & Garcia et al. 2005 \\
Chaparral & 204 & Severe & Glendenning et al. 1961 \\
Mixed conifer & 370 & Severe & Hendricks 1944 \\
\hline
\end{tabular}

is the loss of hydrologic function (DeBano et al. 1998). Again, the level of hydrologic function loss is related to fire severity. Although this ecosystem function tends to recover within $5 \mathrm{yr}$ to $10 \mathrm{yr}$ after wildland fire as vegetation cover returns, the immediate impacts can be considerable. The removal of the protective layer of the forest floor by combustion and the development of water repellent layers in the soil exacerbates flood potential (Neary et al. 2005). Peak flows after wildland fires with high percentages of areas classified as high severity fire $(>30 \%)$ commonly have increases of ten-fold. Higher increases (twenty- to twothousand-fold) have been measured as the aerial percentage of high-severity soil damage approaches $100 \%$. High flood runoff reduces baseflow as a result of the reduction in rainfall infiltration into the soil. This has water quantity implications for forested watersheds that are sources for municipal water supplies. In addition, post-wildland fire ash slurry flows can substantially degrade the quality of municipal water sources for up to $2 \mathrm{yr}$ post-fire.

\section{Non-Native Vegetation Changes}

Non-native plants invade areas that have been subjected to desertification caused by wildland fire. There are a number of well documented cases where high severity wildland fires have resulted in elevated establishment of non-native plant species (Crawford et al. 2001, Griffis et al. 2001, Neary et al. 2004). Nonnative plants are opportunistic invaders on sites where the soil has been disturbed by pre- scribed fire and mechanical thinning. Non-native plant establishment in areas burned by high severity wildland fire can be up to 12 times higher than on sites with medium or low burn severities. Plants such as cheatgrass (Bromus tectorum), buffelgrass (Pennisetum ciliare), and red brome (Bromus rubens), respond rapidly to fire, out-compete native grasses, and then alter the fire regime, producing more frequent and hotter fires (Grace et al. 2001). Successful invasions by these plants aggravate the desertification problem caused by post-wildland fire erosion. One problem that has been minimized but not totally eliminated is non-native seed contamination of native plant seed sources. Even where certified weed-free native plant seed is used, there are still low levels $(0.1 \%)$ of weed seed contamination.

\section{BURNED AREA EMERGENCY RESPONSE}

The first formal efforts of emergency watershed rehabilitation after wildland fires began in the 1960s and early 1970s (Robichaud et al. 2000), although post-fire seeding with grasses and other herbaceous species was conducted in many areas in the 1930s, 1940s, and 1950s (Christ 1934, Gleason 1947). The Forest Service and other land management agencies (Bureau of Land Management, National Park Service, and Department of Defense) had no formal emergency rehabilitation in the early 1970s. Although funds for fire suppression were covered by fire suppression authoriza- 
tions, watershed rehabilitation funding of the type considered for Burned Area Emergency Response was obtained from emergency flood control programs or, more commonly, stand restoration accounts.

A congressional inquiry in 1974 led to a formal authority for $\$ 2$ million in post-fire rehabilitation activities. Originally called Burned Area Emergency Rehabilitation (BAER), this authorization was similar to fire fighting funds in that it allowed the Forest Service to use any available funds to cover the costs of watershed treatments when an emergency need was determined and authorized. Later, similar authorities were provided for the Bureau of Land Management and other Department of the Interior agencies. The occurrence of many large fires in California and southern Oregon in 1987 caused expenditures for Burned Area Emergency Response treatments to exceed the annual program authorization of \$2 million. Congressional committees were consulted and the funding cap was removed.

After the \$2 million cap was removed and policies were refined based on determining what constituted a legitimate emergency warranting rehabilitation treatments, the Burned Area Emergency Response program began to evolve (Robichaud et al. 2000). The program evolved further by a change in the name to Burned Area Emergency Response since it had become quite evident that rehabilitation couldn't be achieved in the short timeframe that BAER was operative ( $<2$ years). The BAER-related policies required an immediate assessment of site conditions following wildland fire and, where necessary, implementation of emergency rehabilitation measures. These directives delineated the objectives of the Burned Area Emergency Response program.

The objectives of the Burned Area Emergency Response program were to:
1. Minimize the threat to life and property onsite and offsite.

2. Reduce soil loss and impacts to on-site productivity.

3. Reduce flooding potential.

4. Reduce deterioration of water quality.

As post-fire Burned Area Emergency Response treatment experience increased, debates arose over the effectiveness of a commonly used treatment, herbaceous plant seeding, and its negative impacts on natural regeneration (Robichaud et al. 2000). Although seeding of grasses and other plants has been done to reduce erosion, it raises the question about the other component of desertification-introduction of non-native plants. Seeding was the most widely used individual treatment and it was often applied in conjunction with other treatments. In the mid $1990 \mathrm{~s}$, the issue of using native species for emergency revegetation emerged as a major topic. The increased use of contour-felled logs (Figure 4) and mulches caused rehabilitation expenditures to escalate. During the 1996 fire season, the Forest Service spent $\$ 11$ million on BAER projects. In 2000, 2001, and 2002, the average annual Burned Area Emergency Response spending rose to more than \$50 million due to fires such as the Cerro Grande, Rodeo-Chediski, Hayman, and Biscuit fires (Robichaud et al. 2005).

A modification of the US Forest Service Burned Area Emergency Response program in 2000, which resulted from the Robichaud et al. (2000) report, allowed individual land management units to obtain funds. The intent of this was to provide an incentive and the means to obtain treatment effectiveness data that are mostly lacking. This information is critically needed to support future Burned Area Emergency Response treatment recommendations. 

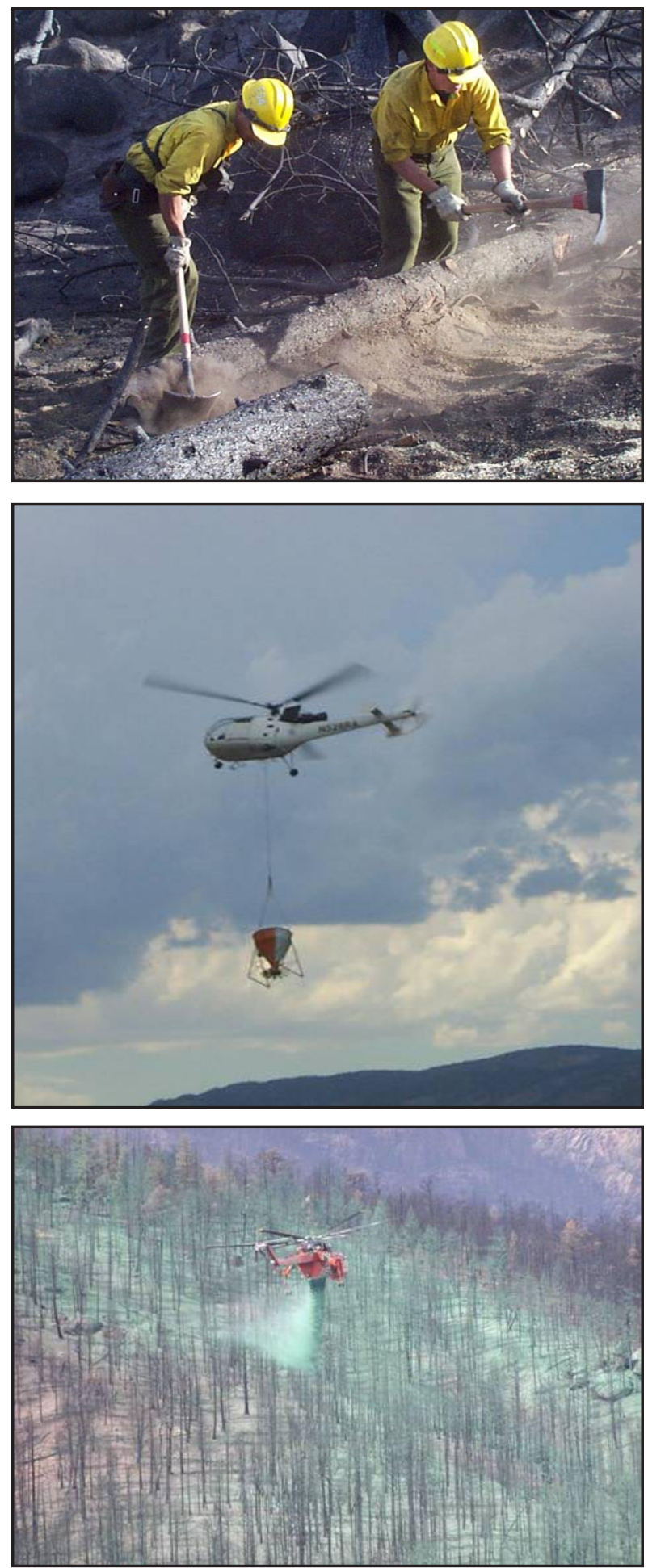

Figure 4. BAER hillslope treatments to reduce erosion: (top) log erosion barriers, (middle) aerial seeding, and (bottom) hydro mulching. (Photos by Peter R. Robichaud.)

\section{BURNED AREA EMERGENCY RESPONSE TREATMENTS}

Early Burned Area Emergency Response efforts were principally aimed at controlling runoff and, consequently, erosion. Research by Noble (1965) and others demonstrated that various watershed management techniques could be used on forest, woodland, shrub, and grassland watersheds to control both storm runoff and erosion. Many of these techniques were developed from other disciplines (such as agriculture and construction) and refined or augmented to form the set of Burned Area Emergency Response treatments in use today (Table 6). In spite of the improvements in the process and the wealth of practical experience obtained over the past several decades, the effectiveness of many emergency rehabilitation methods have not been systematically tested or validated. Measuring erosion and runoff is expensive, complex, and labor intensive. Few researchers or management specialists have the resources or the energy to conduct the measurements. Burned Area Emergency Response team leaders and decision makers often do not have information available to evaluate the short- and long-term benefits (and costs) of various treatment options. In 1998, a joint study by the Forest Service Rocky Mountain Research Station and the Pacific Southwest Research Station evaluated the use and effectiveness of post-fire emergency rehabilitation methods (Robichaud et al. 2000).

Some of the newer techniques that became popular since the Robichaud et al. (2000) report included wood mulch made from on-site wood resources, hydro mulch, and polyacrylamide (PAM; a synthetic, high molecular weight organic polymer that dissolves in water and can be used to control soil erosion). However, these techniques could be very expensive, costing $\$ 2000$ to $\$ 5000 \mathrm{ha}^{-1}$ to apply. 
Table 6. Burned Area Emergency Rehabilitation (BAER) treatments. (Adapted from Robichaud et al. 2000.)

\begin{tabular}{lll}
\hline Hillslope & Channel & Road and trail \\
\hline Broadcast seeding & Straw bale check dams & Rolling dips \\
Seeding plus fertilizer & Log grade stabilizers & Water bars \\
Mulching & Rock grade stabilizers & Cross drains \\
Contour-felled logs & Channel debris clearing & Culvert overflows \\
Contour trenching & Bank/channel armoring & Culvert upgrades \\
Scarification and ripping & In-channel tree felling & Culvert armoring \\
Temporary fencing & Log dams & Culvert removal \\
Erosion fabric & Debris basins & Trash racks \\
Straw wattles & Straw wattle dams & Storm patrols \\
Slash scattering & Rock gabion dams & Ditch improvements \\
Silt fences & & Armored fords \\
Geotextiles & & Outsloping \\
Sand or soil bags & & Signing \\
\hline
\end{tabular}

\section{BURNED AREA EMERGENCY RESPONSE EFFECTIVENESS AND DESERTIFICATION}

The Robichaud et al. (2000) analysis found very little quantitiative data to support cost and benefit analyses for most Burned Area Emergency Response treatments. As mentioned previously, these data are very scarce. Efforts have been underway since 2000 to fill in data gaps (Robichaud et al. 2005). Team members were surveyed to obtain their best professional judgment on which treatments are effective and which are not.

Robichaud and Elliot (2006) evaluated a number of Burned Area Emergency Response treatments for $2 \mathrm{yr}$ after the 2002 Hayman Fire. They reported that wood and straw mulch reduced erosion rates by $60 \%$ to $80 \%$, contourfelled log erosion barriers $50 \%$ to $70 \%$, and that hydro mulch and grass seeding had little effect the first year when rainfall events were small and intensities low. The burned but untreated areas were classified as high to severe desertification both years. The wheat straw kept desertification in the none to slight category the first year, but in the following year it rose to moderate. The hydro mulch kept ero- sion in the moderate to severe range, so it was not very effective in reducing post-fire desertification.

Seeding with white winter wheat (Triticum estivum) and additions of fertilizer after a wildland fire in north-central Washington did not reduce significant desertification-related erosion the first year (Robichaud et al. 2006). Soil loss varied from $31 \mathrm{Mg} \mathrm{ha}^{-1} \mathrm{yr}^{-1}$ to $16 \mathrm{Mg}$ $\mathrm{ha}^{-1} \mathrm{yr}^{-1}$, putting that application in the high to moderate categories. However, in the second year, erosion was reduced to the very low to low level. This follows the trend in seeding reported by Robichaud et al. (2000) that seeding of herbaceous plants works to control erosion mostly from year 2 onwards. Similar results from native plant seeding after the Rodeo-Chediski Fire of 2002 were reported by Garcia (2005). Erosion during the first year after the fire was high in the severe range for desertification (109 $\mathrm{Mg} \mathrm{ha}^{-1}$; Table 3), but it was reduced by half in the second year as forest herbaceous vegetation recovered (Figure 5). The seeding was ineffective at reducing or preventing desertification because of the timing differences between first storm events and plant germination. The results from the Rodeo-Chediski Fire of 2002 reinforced concerns 


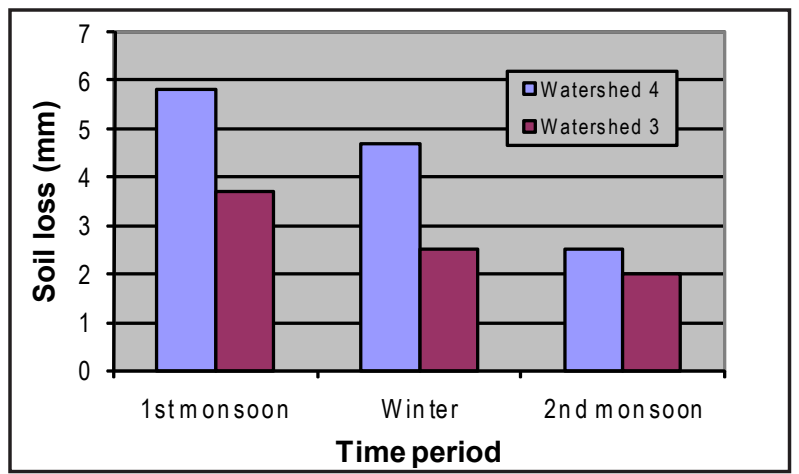

Figure 5. Soil loss after BAER treatments with native plant seeding on the Stermer Ridge watersheds after the Rodeo-Chediski Fire of 2002. Watershed 3 was burned with a high severity fire and watershed 4 with a moderate severity fire. (From Garcia et al. 2005.)

raised by Robichaud et al. (2000) on the efficacy of seeding in reducing post-fire erosion. There is also the issue of non-native plant introductions into seeded areas, even when certified seed is used. Burned Area Emergency Response treatments must be evaluated in a range of ecosystems to evaluate both their effectiveness at improving post-fire environmental conditions and counteracting desertification.

In a study conducted throughout the west, the Burned Area Emergency Response treatment of using log erosion barriers was found to be ineffective at reducing erosion (Robichaud et al. 2008). Although log erosion barriers were highly rated in professional surveys, they failed to provide adequate erosion prevention in storms with a $>2 \mathrm{yr}$ return period. The storms that produce runoff in excess of a $2 \mathrm{yr}$ return interval are the ones that produce the high erosion rates that lead to desertification.

Additional monitoring and research is needed to adequately evaluate all the BAER treatments available to watershed managers to determine both cost effectiveness and ability to minimize desertification. Provisions and funds exist for land managers to monitor BAER treatments to get quantifications of reductions in erosion and non-native plant invasions. However, these opportunities are not being adequately utilized, and the opportunity to guide future BAER treatments are lost.

\section{MANAGEMENT IMPLICATIONS}

Wildland managers need to be more aware of the long-term impacts of wildland fires on soils and ecosystem integrity. Once these fires are extinguished, their impacts linger long into the future. There are several important management implications that can be derived:

1. Land managers need to be diligent in reducing fuel loads to prevent high severity wildland fires. Prevention of catastrophic fires is much more cost effective in both economic and environmental terms.

2. Some Burned Area Emergency Response techniques are effective in mitigating wildland fires and some are not. Managers need to be aware of this and not rely on these mitigation techniques to be "magic fixes" that can make everything whole again.

3. Both new and old Burned Area Emergency Response techniques need to be evaluated across a range of ecosystems to determine whether they are environmentally effective in reducing erosion and preventing desertification.

4. Climate change is happening now and soil responses to wildland fires can and will change, affecting future landscape productivity and sustainability.

5. Managers need to work closely with their staffs, local universities, agencies, and consulting soil scientists to plan appropriate management responses to wildland fire disturbances.

6. Burned Area Emergency Response techniques that return some functionality to impacted soils (e.g., mulching) have the greatest probability of reducing desertification. 


\section{SUMMARY AND CONCLUSIONS}

In this paper, I have introduced the concept of desertification as it relates to wildland fire. The principal components of desertification are erosion and non-native plant invasions. I also examined the capability of Burned Area Emergency Response treatments to mitigate potential desertification. There is a growing body of knowledge on the effectiveness of these post-fire mitigation treatments, but it is still quite limited given the enormous combi- nation of fire severities, sites, climates, soils, and fire behavior in the southwestern US. Many treatments commonly used in the past, such as seeding and log erosion barriers, do not adequately prevent desertification. Treatments such as wood and wheat straw mulching show promise in reducing soil erosion and limiting invasive plant colonization, but are very expensive. In order to justify the costs involved in reducing wildland fire-related desertification, considerably more quantitative monitoring is needed.

\section{ACKNOWLEDGEMENTS}

The author would like to acknowledge the US Forest Service Burned Area Emergency Response Program, the National Fire Plan, the US Forest Service Research and Development staff, and the Rocky Mountain Research Station for supporting the work done as part of this analysis.

\section{LITERATURE CITED}

Aubreville, A. 1949. Climats, forêts et désertification de l'Afrique tropicale. Société d'Editions Géographiques, Maritimes et Coloniales, Paris, France.

Black, P.E. 1997. Watershed functions. Journal of the American Water Resources Association 33: 1-11.

Brown, D.E., editor. 1982. Biotic communities of the American southwest-United States and Mexico. Desert Plants 1: 1-342.

Brown, J.K., and J.K. Smith, editors. 2000. Wildland fire in ecosystems: effects on flora. USDA Forest Service General Technical Report RMRS-GTR-42, Volume 2.

Campbell, R.E., M.B. Baker, Jr., P.F. Ffolliott, F.R. Larson, and C.C. Avery. 1977. Wildland fire effects on a ponderosa pine ecosystem: an Arizona case study. USDA Forest Service Research Paper RM-191.

Christ, J.H. 1934. Reseeding burned-over lands in northern Idaho. University of Idaho Agricultural Experiment Station Bulletin 201.

Crawford J.S., C.H.A. Wahren, S. Kyle, and W.H. Moir. 2001. Responses of non-native plant species to fires in Pinus ponderosa forests in northern Arizona. Journal of Vegetation Science 12: 261-268.

Davenport, D.W., D.D. Breshears, B.P. Wilcox, and C.D. Allen. 1998. Viewpoint: sustainability of pinyon-juniper ecosystems: a unifying perspective of soil erosion thresholds. Journal of Range Management 51: 231-240.

Davies, D., S. Kumar, and J. Descloitres. 2004. Global fire monitoring using MODIS near-realtime satellite data. GIM International 18(4): 41-43.

DeBano, L.F., D.G. Neary, and P.F. Ffolliott. 1998. Fire's effects on ecosystems. John Wiley \& Sons, New York, New York, USA. 
Dregne, H.E. 1977. Desertification of arid lands. Economic Geography 53: 322-331.

Dregne, H.E. 1986. Desertification of arid lands. Pages 4-34. in: F. El-Baz and M.H.A. Hassan, editors. Physics of desertification. Martinus Nijhoff, Dordrecht, Netherlands.

European Commission. 2006. Forest fires in Europe 2005. European Commission Joint Research Centre Report No. 6.

FAO. 2008. Desertification. United Nations Food and Agriculture Organization. <http://www. fao.org/desertification/default.asp?lang=en>. Accessed 1 October 2008.

Garcia, P., P.F. Ffolliott, and D.G. Neary. 2005. Soil erosion following the Rodeo-Chediski wildland fire: an initial assessment. Hydrology and Water Resources in Arizona and the Southwest 34: 51-56.

Gleason, C.H. 1947. Guide for mustard sowing in burned watersheds of southern California. San Francisco, California: USDA Forest Service, California Region.

Glendening, G.E., C.P. Pase, and P. Ingebo. 1961. Preliminary hydrologic effects of wildland fire in chaparral. Pages 12-15 in: Proceedings, 5th Annual Arizona Watershed Symposium, 21 September 1962, Phoenix, Arizona. University of Arizona, Tucson, USA.

Grace, J.B., M.D. Smith, S.L. Grace, S.L. Collins, and T.J. Stohlgren. 2001. Interactions between fire and invasive plants in temperate grasslands of North America. Pages 40-65 in: K.E.M. Galley and T.P. Wilson, editors. Proceedings of the invasive species workshop: the role of fire in the control and spread of invasive species. Fire Conference 2000: the First National Congress on Fire Ecology, Prevention, and Management. Tall Timbers Research Station Miscellaneous Publication No. 11.

Griffis K.L., J.A. Crawford, M.R. Wagner, and W.H. Moir. 2001. Understory response to management treatments in northern Arizona ponderosa pine forests. Forest Ecology and Management 146: 239-245.

Hendricks, B.A., and J.M. Johnson. 1944. Effects of fire on steep mountain slopes in central Arizona. Journal of Forestry. 42: 568-571.

Larson, W.E., F.J. Pierce, and R.H. Dowdy. 1983. The threat of soil erosion to long-term crop production. Science 219: 458-465.

MacDonald, L.H. 2000. Evaluating and managing cumulative effects: process and constraints. Environmental Management 26(3): 299-315.

Malhi, Y., J. Roberts, R. Betts, T. Killeen, W. Li, and C. Nobre. 2008. Climate change, deforestation, and the fate of the Amazon. Science 319(5860): 169-172.

McCormack, D.E., K.K. Young, and L.W. Kimberlin. 1979. Current criteria for determining soil loss tolerance. Chapter 9 in: B.L. Schmidt, R.A. Allmaras, J.V. Mannering, and R.I. Papendick, editors. Determinants of soil loss tolerance. American Society of Agriculture Special Publication Number 45.

Millennium Ecosystem Assessment. 2005a. Ecosystems and human well-being: desertification synthesis. World Resources Institute, Washington, DC, USA. <http://www.millenniumassessment.org/documents/document.355.aspx.pdf>. Accessed 1 October 2008.

Millennium Ecosystem Assessment. 2005b. Ecosystems and human well-being: general synthesis. Island Press, Washington, DC, USA. <http:/www.millenniumassessment.org/documents/ document.355.aspx.pdf $>$. Accessed 1 October 2008.

National Interagency Fire Center. 2009. Fire information-wildland fire statistics. <http://www. nifc.gov/fire_info/fires_acres.htm>. Accessed 1 October 2008. 
National Oceanographic and Atmospheric Administration (NOAA). 2006. < http://rapidfire.sci. gsfc.nasa.gov/firemaps/)>. Accessed 1 October 2008.

Natural Resources Conservation Service (NRCS). 1993. Soil survey manual. US Department of Agriculture, Handbook 18.

Neary, D.G. 2002. Hydrologic values. Pages 36-67 in: J. Richardson, T. Smith, and P. Hakkila, editors. Bioenergy from sustainable forestry: guiding principles and practices. Elsevier, Amsterdam, Netherlands.

Neary, D.G. 2006. A global view of forest fires and desertification: environmental and socioeconomic consequences. Proceedings, Conferência Internacional sobre Incêndios e Desertificaçã, Lisbon, Portugal, 30 October 2006, Comissão Nacional de Coordenação do Programa de Acção Nacional de Combate à Desertificação. General Directorat of Forestry Resources, Lisbon, Portugal.

Neary, D.G., and J.W. Hornbeck. 1994. Chapter 4: Impacts of harvesting practices on off-site environmental quality. Pages 81-118. in: W.J. Dyck, D.W. Cole, and N.B. Comerford, editors. Impacts of harvesting on long-term site productivity. International Energy Agency project A6 Book. Chapman and Hall, London, United Kingdom.

Neary, D.G., W.H. Moir, and B. Phillips. 2004. Harvesting related soil disturbance: implications for plant biodiversity and invasive weeds. Pages 364-371 in: D.S. Pavlo and G.K. Scherbina, editors. Invasions of alien species in the holarctic. Proceedings of the US-Russia Invasive Species Workshop, 27-31 August 2001, Borok, Russia. Special Publication, Russian Academy of Science, I.D. Papanin Institute of Biology of Inland Waters, and the A.N. Severtsov Institute of Ecology and Evolution, Yaroslavl, Russia.

Neary, D.G., C.C. Klopatek, L.F. DeBano, and P.F. Ffolliott. 1999. Fire effects on belowground sustainability: a review and synthesis. Forest Ecology and Management 122: 51-71.

Neary, D.G., K.C. Ryan, and L.F. DeBano, editors. 2005. Wildland fire in ecosystems: effects on soil and water. USDA Forest Service General Technical Report RMRS-GTR-42-volume 4.

Noble, E.L. 1965. Sediment reduction through watershed rehabilitation. Pages 114-123 in: Proceedings of the federal inter-agency sedimentation conference, 1963. USDA Agriculture Research Service Miscellaneous Publication 1970.

Pase, P.C., and P.A. Ingebo. 1965. Burned chaparral to grass: early effects on water and sediment yields from two granitic soil watersheds in Arizona. Pages 8-11 in: Proceedings of the 9th Annual Arizona Watershed Symposium, 22 September 1965, Tempe, Arizona, USA.

Pires, V., and A. Silva. 2008. Analyses of droughts historical evolution in mainland Portugal. European Meteorological Society, European Civil Aviation Conference, Abstracts, Volume 5, EMS2008-A-00018, 2008, 8th Annual Meeting of the European Meteorological Society and 7th European Civil Aviation Conference Annual Meeting.

Pyne, S.J. 1995. World fire: the culture of fire on Earth. Henry Holt, New York, New York, USA.

Requier-Desjardins, M. 2006. The economic costs of desertification: a first survey of some cases in Africa. International Journal of Sustainable Development 9:199-209.

Reynolds, D.M., and D.M. Stafford-Smith. 2002. Global desertification: do humans cause deserts? Dahlem University Press, Berlin, Germany.

Robichaud, P.R., and W.J. Elliot. 2006. Protection from erosion following wildland fire. American Society of Agricultural and Biological Engineers Paper Number 068009. 
Robichaud, P.R., J.L. Beyers, and D.G. Neary. 2000. Evaluating the effectiveness of post-fire rehabilitation treatments. USDA Forest Service General Technical Report RMRS-GTR-63.

Robichaud, P.R., J.L. Beyers, and D.G. Neary. 2005. Post-fire watershed rehabilitation. Pages 179-198 in: D.G. Neary, K.C. Ryan, and L.F. DeBano, editors. Fire effects on soil and water. USDA Forest Service General Technical Report RMRS-GTR-42-volume 4.

Robichaud, P.R., T.R. Lillybridge, and J.W. Wagenbrenner. 2006. Effects of postfire seeding and fertilization on hillslope erosion in north-central Washington, USA. Catena 67:56-67.

Robichaud, P.R., J.W. Wagenbrenner, R.E. Brown, P.M. Wohlgemuth, and J.L. Beyers. 2008. Evaluating the effectiveness of contour-felled log erosion barriers as a post-fire runoff and erosion mitigation treatment in the western United States. International Journal of Wildland Fire 17:255-273.

Schmidt, B.L., R.R. Allmaras, J.V. Mannering, and R.I. Papendick, editors. 1982. Determinants of soil loss tolerance. Proceedings of a symposium, sponsored by Division S-6 of the Soil Science Society of America. American Society of Agronomy Special Publication No. 45.

Scott, A.C. 2000. The pre-quaternary history of fire. Palaeogeography, Palaeoclimatology, Palaeoecology 164: 281-329.

Smith, J.K, editor. 2000. Wildland fire in ecosystems: effects on fauna. USDA Forest Service, Rocky Mountain Research Station, General Technical Report RMRS-GTR-42-volume 1.

Soulé, P.T. 2006. Spatial patterns of drought frequency and duration in the contiguous USA based on multiple drought event definitions. International Journal of Climatology 12: 11-24.

Stringer, L.C. 2008. Reviewing the international year of deserts and desertification 2006: what contribution towards combating global desertification and implementing the United Nations convention to combat desertification? Journal of Arid Environments 72: 2065-2072.

Tebaldi, C., K. Hayhoe, J.M. Arblaster, and G.A. Meehl. 2006. Going to the extremes: an intercomparison of model-simulated and future changes in extreme events. Climate Change 79: $185-211$.

UNCCD. 2008. United Nations Convention to Combat Desertification. <http://www.unccd. int $/>$. Accessed 1 October 2008.

USDA Forest Service. 2006. Southwest Coordination Center. <http://gacc.nifc.gov/swcc/>. Accessed 1 October 2008.

Walker, A.S. 1997. Deserts: geology and resources. <http://pubs.usgs.gov/gip/deserts/>. Accessed 1 October 2008.

Westerling, A.L., H.G. Hidalgo, D.R. Cayan, and T.W. Swetnam. 2006. Warming and earlier spring increase western US forest wildland fire activity. Science 313: 940-943.

Williams, J., and L. Hamilton. 2005. The mega-fire phenomenon: toward a more effective management model. The Brookings Institution, Center for Public Policy Education, Washington, D.C., USA. 